\title{
Correction to: Trastuzumab Emtansine: A Review of Its Adjuvant Use in Residual Invasive HER2-Positive Early Breast Cancer
}

\author{
Katherine A. Lyseng-Williamson ${ }^{1}$
}

Published online: 13 November 2020

C) Springer Nature Switzerland AG 2020

\section{Correction to: Drugs (2020) 80:1723-1730 https://doi.org/10.1007/s40265-020-01408-7}

The author has alerted us to the following error:

\section{Page 1727, column 2, section 7, paragraph 1.}

The paragraph, which is directly below the section title ' 7 Place of Adjuvant Trastuzumab Emtansine in Early Breast Cancer', which reads

'The development of certain AEs (Table 4) may require one or two reductions in the dose of trastuzumab emtansine (i.e. from 3.6 to $3.0 \mathrm{mg} / \mathrm{kg}$, then to $2.4 \mathrm{mg} / \mathrm{kg}$ ), treatment interruption and/or treatment discontinuation $[10,11]$. Consult local prescribing information for further details regarding the use of trastuzumab emtansine.'

Should be located directly above the section 7 heading (i.e. the final paragraph in the section titled ' 6 Dosage and Administration of Trastuzumab Emtansine').

The original article has been updated.

The original article can be found online at https://doi.org/10.1007/ s40265-020-01408-7.

Katherine A. Lyseng-Williamson

demail@springer.com

1 Springer Nature, Private Bag 65901,

Mairangi Bay, Auckland 0754, New Zealand 